\title{
Tax Avoidance: Good Corporate Governance
}

(Studi Kasus Perusahaan Pertambangan Terdaftar di BEI 2015-2018)

\author{
Moh. Ubaidillah \\ Universitas PGRI Madiun \\ mohubaidillah03@mail.com
}

*Corresponding Author

Submitted: August 17, 2020

Accepted: October 28, 2020

Published: February 1, 2021

\begin{abstract}
Tax is an important element for the government but it becomes a burden for companies, so companies do tax evasion legally or illegally to reduce the tax burden. The purpose of this research is to determine the influence of good corporate governance (Institutional Ownership, Independent Commissioners, Audit Committee and Audit Quality) on Tax Avoidance. Independent variables in this study are Institutional Ownership, Independent Commissioners, Audit Committee and Audit Quality, while dependent variables are tax avoidance. This research was taken from mining companies listed on the IDX in 2015-2018. The population in the corporate sector is 47 companies. The samples were studied by 10 companies selected using purposive sampling techniques so that the total samples used for 4 years became 40 samples. The analysis method used is multiple linear regression analysis with SPSS 22 tool. Partial test results showed that the independent board of commissioners had a significant negative effect on tax avoidance, institutional ownership had a significant positive effect on tax avoidance, while the audit committee and the quality of audits had no effect on tax avoidance on mining companies. The results of this study can be concluded that to suppress tax avoidance, the function of independent commissioners must be strengthened.
\end{abstract}

Keywords: tax avoidance, goog corporate governance

\section{Latar Belakang}

\section{PENDAHULUAN}

Pajak merupakan unsur penting dalam menopang penerimaan negara. Dilain pihak, pajak ditempatkan sebagai salah satu kewajiban dalam bernegara, yaitu sebagai sarana masyarakat untuk ikut berpartisipasi dalam rangka membantu pelaksanaan tugas bernegara yang ditangani oleh pemerintah. Terdapat perbedaan kepentingan antara pemerintah dan perusahaan selaku wajib pajak. Pajak di mata negara merupakan sumber penerimaan untuk membiayai penyelenggaraan pemerintahan, namun bagi perusahaan pajak adalah beban yang akan mengurangi laba bersih yang dihasilkan oleh perusahaan. Hal ini menyebabkan perusahaan cenderung mencari cara untuk mengurangi jumlah pembayaran pajak, baik secara legal maupun ilegal (Ngadiman dan Puspitasari, 2014: 409).

Salah satu industri yang melakukan penghindaran pajak adalah industri pertambangan, hal ini diungkapkan oleh Komisi Pemberantasan Korupsi (KPK) bahwa sektor pertambangan ini sektor yang rawan praktik korupsi, salah satunya penghindaran pajak. KPK pernah mencatat kekurangan pembayaran pajak tambang di kawasan hutan sebesar Rp15,9 triliun per tahun. (DDTCNews, 2019).

Pelaku industri pertambangan relatif tidak mendapatkan pengawasan yang memadai, sehingga sering kali terjadi kasus kerusakan lingkungan dan praktik-praktik imoral berupa penghindaran pajak. Anggapan ini muncul karena kurangnya good corporate governace di industri pertambangan.

Mekanisme dalam pengawasan corporate governance ada internal dan external. Mekanisme Internal adalah cara untuk pengendalikan perusahaan dengan menggunakan struktur dan proses internal seperti Rapat Umum Pemegang Saham (RUPS), komposisi Dewan Direksi, proporsi 
Dewan Komisaris dan pertemuan dengan board of director. Sedangkan mekanisme external adalah seperti pengendalian oleh perusahaan, struktur kepemilikan, dan pengendalian pasar. Pada penelitian ini, penerapan corporate governance akan dilihat dari mekanismenya dengan proksi kepemilikan institusional, proporsi Dewan Komisaris Independen, komite audit dan kualitas audit (Rahmi Fadhilah, 2014).

Peneliti mencoba meneliti terkait penghidaran pajak (tax avoidance) diperusahaan pertambangan karena beragam isu praktik menghindaran pajak yang disebabkan oleh lemahnya good corporate governace diperusahaan tersebut. Penelitian ini merupakan replikasi dari penelitian Rahmi Fadhilah (2014) yang berjudul pengaruh good corporate governace terhadap tax avoidance. Sampel penelitiannya pada perusahaan maufaktur yang terdaftar di BEI 2009-2011. Mekanisme good corporate governace yang digunakan adalah kepemilikan institusional, Dewan Komisaris Independen, komite audit dan kualitas audit sebagai variabel independen. Penelitian lainnya terkaitn corporate governance terhadap tax avoidance yang diteliti oleh Sumatri, Aggraeni dan Kusnawan (2018) pada perusahaan industri metal yang terdaftar BEI 2012-2016. Selanjutnya, penelitian yang dilakukan oleh Winata (2014) corporate governance terhadap tax avoidance pada perusahaan yang terdaftar di BEI tahun 2013. Annisa dan Kurniasih (2012) juga penelitian tentang corporate governance terhadap tax avoidance pada perusahaan yang terdaftar BEI pada tahun 2008.

Perbedaan penelitian ini dengan penelitian Rahmi Fadhilah (2014) dan penelitian lainnya adalah pada sampel penelitian. Penelitian ini berfokus pada perusahaan pertambangan karena berbagai isu tentang penghindaran pajak dengan sampel pada perusahaan pertambangan yang terdaftar BEI 2015-2018. Tujuan penelitian ini adalah untuk mengetahui pengaruh good corporate governance (kepemilikan institusional, dewan komisaris independen, komite audit dan kualitas audit) terhadap tax avoidance. Maka peneliti mengambil judul Tax Avoidance: Good Corporate Governace (Studi Kasus pada Perusahaan Pertambangan yang Terdaftar Di BEI 2015-2018)

\section{Rumusan Masalah}

Adapun rumusan dalam penelitian ini adalah:

1. Apakah kepemilikan institusional berpengaruh terhadap tax avoidance pada perusahaan pertambangan yang terdaftar di BEI 2015-2018?

2. Apakah dewan komisaris independen berpengaruh terhadap tax avoidance pada perusahaan pertambangan yang terdaftar di BEI 2015-2018?

3. Apakah komite audit berpengaruh terhadap tax avoidance pada perusahaan pertambangan yang terdaftar di BEI 2015-2018?

4. Apakah kualitas audit berpengaruh terhadap tax avoidance pada perusahaan pertambangan yang terdaftar di BEI 2015-2018?

\section{Tax Avoidance}

\section{STUDI LITERATUR}

Menurut Dyreng dkk (2008) tax avoidance atau penghindaran pajak adalah segala bentuk kegiatan yang memberikan efek terhadap kewajiban pajak, baik kegiatan khusus untuk mengurangi pajak atau kegiatan yang diperbolehkan. Biasanya tax avoidance dilakukan dengan memanfaatkan kelemahan-kelemahan hukum pajak dan tidak melanggar hukum perpajakan. Menurut Suandy 2008) meminimalisasi beban pajak dapat dilakukan dengan berbagai cara, mulai dari yang masih berada dalam bingkai peraturan perpajakan sampai dengan yang melanggar peraturan perpajakan. Upaya untuk meminimalkan dengan perencanaan pajak. Umumnya perencanaan pajak merujuk pada proses merekayasa usaha dan transaksi wajib pajak supaya utang pajak berada dalam jumlah minimal tetapi masih dalam bingkai peraturan perpajakan.

Pengukuran terkait tax avoidance dilakukan dengan menggunakan proksi book tax gap sebagai alat ukur berikut.

Book ta gap $=$ Laba sebelum pajak - laba kena pajak 


$$
\text { Laba Kena Pajak }=\frac{(\text { Beban Pajak Kini })}{25 \%}
$$

\section{Komite Audit}

Menurut Dewi dan Jati (2014) komite audit adalah komite yang bertanggung jawab mengawasi audit eksternal dan merupakan kontak utama antara auditor dengan perusahaan. Menurut Siallagan (2006) Kualifikasi terpenting dari anggota komite audit terletak pada common sense, kecerdasan dan suatu pandangan yang independen. Komite audit meningkatkan integritas dan kredibilitas pelaporan keuangan melalui pengawasan atas proses pelaporan termasuk sistem pengendalian internal, penggunaan prinsip akuntansi berterima umum dan mengawasi proses audit secara keseluruhan.

Menurut Fadhila (2014) pengukuran komite audit dapat digunakan jumlah Komite Audit dalam suatu perusahaan sebagai alat ukur dan variabel dalam penelitian ini

\section{Kepemilikan Institusi}

Menurut Sujoko (2007) kepemilikan institusional adalah proporsi kepemilikan saham oleh institusi pendiri perusahaan, bukan institusi pemegang saham publik yang diukur dengan persentase jumlah saham yang dimiliki oleh investor institusi intern. Menurut Sihaloho dan Pratomo (2014: 3) Kepemilikan Instituional dapat diukur sebagai berikut:

$$
\text { Kepemiliakan Institusional }=\frac{\text { Jumlah Saham Institusional }}{\text { Total Saham yang beredar }}
$$

\section{Komisaris Independen}

Menurut Pohan (2008) Komisaris independen didefinisikan sebagai seorang yang tidak terafiliasi dalam segala hal dengan pemegang saham pengendali, tidak memiliki hubungan afiliasi dengan direksi atau dewan komisaris serta tidak menjabat sebagai direktur pada suatu perusahaan yang terkait dengan perusahaan pemilik menurut peraturan yang dikelurkan oleh BEI, jumlah komisaris independen proporsional dengan jumlah saham yang dimiliki oleh pemegang saham yang tidak berperan sebagai pengendali dengan ketentuan jumlah komisaris independen sekurangkurangnya tiga puluh persen (30\%) dari seluruh anggota komisaris, disamping hal itu komisaris independen memahami undangundang dan peraturan tentang pasar modal serta diusulkan oleh pemegang saham yang bukan merupakan pemegang saham pengendali dalam Rapat Umum Pemegang Saham. Menurut Sandy dan Lukviaman (2015: 91) Komisarin Independen dapat diukur dengan:

$$
\text { Komisaris Independen }=\frac{\text { Jumlah dewan komisaris independen }}{\text { Total anggota dewan komisaris }}
$$

\section{Kualitas Audit}

Rodoni Kualitas Audit diukur dengan besar kecil Kantor Akuntan Publik (KAP). KAP adalah tempat legal profesi auditor yang diberikan oleh Kemenku, yang dibedakan menjadi 2 yaitu: KAP besar big-four dan non-bigfour. (Randal, Beasly, Arens, \& Jusuf. 2013). KAP yang big-four diberi nilai 1, sedangkan non-bigfour diberi nilai 0 .

\section{Kerangka Pemikiran}

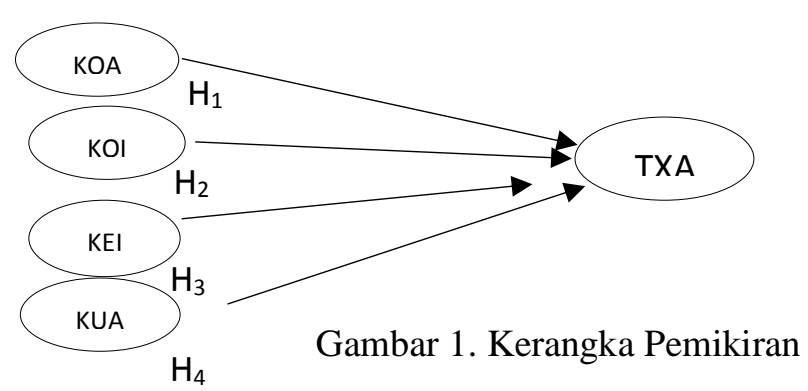


Keterangan:

KOA: Komite Audit

KOI: Komisaris Independen

KEI: Kepemilikan Institusional

KUA: Kualitas Audit

TXA: Tax Avoidance

\section{Hipotesis Penelitian \\ Pengaruh komite audit terhadap tax avoidance}

Teori agensi merupakan teori yang di identik dengan principal dan agent yang diasumsikan sebagai orang yang memiliki rasional ekonomis yang dimotivasi oleh kepentingan pribadi, tetapi mereka mungkin berbeda rasa dalam preferences, beliefs dan informasi. Jensen dan Meckling (1976) menyatakan bahwa hubungan agensi seperti sebuah kontrak dimana satu orang atau lebih (principal) menggunakan orang lain (agent) untuk bekerja atas nama principal dimana termasuk mendelegasikan kewenangan kepada agent untuk membuat beberapa keputusan. Berdasarkan penjelasan diatas dapat dilihat bahwa pada hubungan agensi terdapat hubungan kontraktual dimana pemilik saham sebagai principal menunjuk dan menginginkan manajer atau agent untuk mengelola sumberdaya yang dimiliki oleh principal dalam sebuah perusahaan. Namun demikian, dalam teori agensi juga dikatakan bahwa lama-kelamaan para agent tidak dapat lagi bertindak sesuai dengan kepentingan principal dan cenderung untuk bertindak sesuai kepentingan agent. Hal ini akan menimbulkan asimetri informasi yang berujung ketidak sesuaian pajak.

, yang menyatakan bahwa

Keberadaan komite audit yang fungsinya untuk meningkatkan integritas yang kredibilitas pelaporan keuangan agar dapat berjalan dengan baik. Menurut Sriwedari (2009) komite audit perusahaan berpengaruh terhadap tax avoidance didasarkan dua alasan, yaitu; 1) kecilnya jumlah komite audit yang dimiliki oleh perusahaan, maka akan meminim bentuk pengendalian terhadap kebijakan keuangan, sehingga akan memberikan peluang yang cukup besar bagi manajemen untuk melakukan tindakan penghidaran pajak, sebaliknya semakin besar jumlah komite audit dalam perusahaan, akan meningkatkan pengendalian yang dilakukan terhadapat kebijakan keuangan pada perusahaan, sehingga akan memperkecil kesempatan tindakan manajemen untuk melakukan tindakan tax avoidance. 2) Nama baik perusahaan perusahaan yang memiliki komite audit yang tidak sesuai dengan yang ditetapkan OJK akan mempengaruhi integritas dan kredibilitas keuangan perusahaan, sehingga memberikan peluang yang cukup besar kepada manajemen melakukan tax avoidance.

H1: Komite Audit Berpengaruh terhadap Tax Avoidance

\section{Pengaruh komisaris independen terhadap tax avoidance}

Teori agensi yang sudah dijelaskan sebelumya bahwa principal dan agen mempunyai kepentingan masing-masing yang termotivasi oleh faktor ekonomi sehingga kepentingan principal tidak dilakukan oleh agen sebagai pengolah perusahaan dan hanya bertindak kepentingan pribadi agen sehingga menimbulkan asimetri informasi yang berujung ketidak sesuain pajak. Anggota dalam Dewan Komisaris Independen semuanya harus memiliki kebebasan serta dapat menunjukkan kekuasaannya agar fungsi pengawasan berjalan dengan baik dan berdampak baik pada pengawasan terhadap manajemen dalam melakukan Tax Avoidance. Menurut Anisa dan Kurniasih (2012) semakin besar porsi dewan komisaris independen dapat bekerja secara efektif dalam melakukan pengawasan dan pengendalian terhadap direksi dan manajer dalam pengelolaan perusahaan. Hal yang harus dihindari keberadaan Dewan Komisaris Independen bukan menjadi simbol semata untuk memenuhi ketentuan yang ditetapakan oleh Otoritas Jasa Keuangan. Dengah semakin besarnya porsi Dewan Komisaris Independen dapat mempengaruhi kebijakan tax avoidance yang dilakukan oleh suatu perusahaan.

H2: Komisaris Independen berpengaruh terhadap tax avoidance 


\section{Pengaruh kepemilikan institusional terhadap tax avoidance}

Menurut penelitian dari Ngadiman dan Puspitasari (2014), kepemilikan institusional memiliki pengaruh positif dan signifikan terhadap tax avoidance. Penelitian Cahyono, Andini, Raharjo (2016) mengenai Pengaruh Komite Audit, Kepemilikan Institusional, Dewan Komisaris, Ukuran Perusahaan (Size), Leverage (Der) Dan Profitabilitas (ROA) Terhadap Tindakan Penghindaran Pajak (Tax Avoidance) Pada Perusahaan Perbankan Yang Listing Bei Periode Tahun 2011 - 2013. Dengan hasil penelitian bahwa Kepemilikan Institusional berpengaruh terhadap Tax Avoidance.

Menurut Timothy (2010) semakin besar porsi kepemilikan saham oleh manajerial, dapat dikatakan bahwa konsentrasi kepemilikan didalam perusahaan akan semakin kuat. Jumlah kepemilikan saham yang cukup besar ini akan menjadikan tata kelola perusahaan semakin baik, sebab semakin besarnya kekuatan pemilik untuk mengawasi pihak manajer dalam membuat arah kebijakan perusahaan. Pemegang saham terbesar pada perusahaan bisa dimanfaatkan secara optimal sebagai bentuk mekanisme pengawasan terhadapa masalah keagenan, yang pada akhirnya diharapkan dapat meningkatkan kinerja perusahaan.

H3: Kepemilikan Institusional berpengaruh terhadap tax avoidance

\section{Pengaruh kualitas audit terhadap tax avoidance}

Pengauditan laporan keuangan merupakan suatu kewajiban bagi perusahaan untuk membuktikan transparansi kepada public bahawasannya laporan keuangan tersebut benar-benar apa adanya dan sesuai dengan standar akuntansi yang berlaku umum atau sesuai dengan aturan yang sudah ditentukan. Perusahaan akan memilih jasa kantor akuntan public (KAP) The Big Four atau nonThe Big Four untuk melakukan pengauditan laporan keuangan. Dikatakan berkualitas hasil auditnya jika perusahaan tersebut memilih jasa KAP The Big Four. KAP The Big Four merupakan jasa akuntan yang mengutamakan professional dan independennya sebagai jasa akuntan. Jika perusahaan memilih KAP The Big Four sebagai audit laporan keuangannya, maka penghindaran pajak tidak dilakukan oleh perusahaan tersebut karena berani memilih KAP The Big Four sebagai jasa auditnya.

H4: kualitas audit berpengaruh terhadap tax avoidance

\section{METODE}

Jenis penelitian ini adalah kausatif yang menunjukkan arah hubungan antara variabel bebas dan varibael bebas. Selain menguji hubungan, peneliti menguji pengaruh good corporate governance terhadap tax avoidance.Populasi dalam penelitian ini adalah perusahaan pertambangan yang terdaftar di Bursa Efek Indoenesia (BEI) 2015-2018 sebanyak 47 perusahaan. Sampel penelitian diambil dari populasi yang ada dengan menggunakan teknik purposive sampling yaitu teknik penentuan sampel dengan pertimbangan tertentu (Sugiyono, 2014: 85). Pertimbangan atau kriteria sampel yang digunakan dalam penelitian adalah sebagai berikut:

Tabel 1. Kriteria Pengambilan Sampel Penelitian

\begin{tabular}{|c|l|c|}
\hline No & Keterangan & Jumlah \\
\hline 1 & $\begin{array}{l}\text { PerusahaanPertambangan yang terdaftar di Bursa Efek } \\
\text { Indonesia tahun 2015-2018. }\end{array}$ & 47 \\
\hline 2 & $\begin{array}{l}\text { Perusahaan yang tidak menerbitkan laporan keuangan } \\
\text { audited selama tahun 2015-2018. }\end{array}$ & $(3)$ \\
\hline 3 & $\begin{array}{l}\text { Perusahaan delisting ataupun berpindah sektor selama } \\
\text { periode 2015-2018 }\end{array}$ & $(0)$ \\
\hline 4 & $\begin{array}{l}\text { Perusahaan tidak menggunakan mata uang Rupiah } \\
\text { (IDR) dalam laporan keuangannya selama periode } \\
\text { 2015-2018 }\end{array}$ & $\begin{array}{l}\text { Perusahaan yang tidak memiliki data lengkap } \\
\text { mengenai Good Corporate Governance selama } \\
\text { periode 2015-2018 }\end{array}$ \\
\hline 5 & (2) \\
\hline
\end{tabular}


Owner: Riset \& Jurnal Akuntansi

e-ISSN : 2548-9224 |p-ISSN : 2548-7507

Volume 5 Nomor 1, Februari 2021

\begin{tabular}{|c|l|c|}
\hline 6 & $\begin{array}{l}\text { Perusahaan yang tidak memiliki laba bersih sebelum } \\
\text { pajaknya positif selama tahun 2015-2018 }\end{array}$ & (4) \\
\hline Jumlah Perusahaan & 10 \\
\hline Jumlah data sampel selama 4 tahuan (10x4) & 40 \\
\hline
\end{tabular}

Sumber Tabel: Data diolah (2020)

Metode analisis data untuk pengujian kelayakan model penelitian melalui pengujian asumsi klasik bertujuan untuk mengetahui dan menguji kelayakan atas model regresi yang digunakan dalam penelitian ini. Pengujian ini juga dimaksudkan untuk memastikan bahwa di dalam model regresi yang digunakan tidak terdapat multikolonieritas, autokorelasi dan heteroskedastisitas serta untuk memastikan bahwa data yang dihasilkan berdistribusi normal.

\section{Statistik Deskriptif}

\section{HASIL}

Statistik deskriptif merupakan uji data untuk mengetahui deskripsi data penelitian yang ditunjukkan dari hasil rata-rata sebagai besarnya rata-rata populasi yang diperkirakan dari sampel, maksimum dan minimum nilai dalam populasi dan standar deviasi dalam menilai rata-rata dispersi dari sampel yang digunakan. Hasil analisis statistik deskriptif dapat dilihat di bawah ini sebagai berikut.

Tabel 2. Statistk Deskriptif

\begin{tabular}{|l|r|r|r|r|r|}
\hline & $\mathrm{N}$ & Minimum & Maximum & Mean & $\begin{array}{c}\text { Std. } \\
\text { Deviation }\end{array}$ \\
\hline KOI & 40 & .33 & .60 & .4083 & .07716 \\
\hline KOA & 40 & 1.00 & 4.00 & 2.6000 & .81019 \\
\hline KEI & 40 & .98 & 2.28 & 1.0993 & .24127 \\
\hline KUA & 40 & .00 & 1.00 & .4500 & .50383 \\
\hline TXA & 40 & 10.10 & 12.90 & 11.3473 & .85920 \\
\hline $\begin{array}{l}\text { Valid N } \\
\text { (listwise) }\end{array}$ & 40 & & & & \\
\hline
\end{tabular}

Sumber Tabel: Data Olah SPSS (2020)

\section{Uji Asumsi Klasik}

Uji Normalitas

Hasil regresi yang baik adalah mempunyai distribusi data normal ataupun mendekati normal. Pengujian menggunakan uji One-Sample Kolmogorov-Smirnov Test adalah variabel yang dapat dikatakan berdistribusi normal ketika nilai signifikannya lebih besar dari 0,05 . hasil uji normalitas sebagai berikut:

Tabel 3. Kolmogorov Smirnov

\begin{tabular}{|l|l|r|}
\hline \multicolumn{2}{|l|}{} & \multicolumn{2}{|c|}{ Unstandardized Residual } \\
\hline N & 26 \\
\hline \multirow{2}{*}{ Normal } & Mean & .0000000 \\
\cline { 2 - 3 } Most Extreme & Std. Deviation & .72093155 \\
Differences & Absolute & .113 \\
\cline { 2 - 3 } & Positive & .113 \\
\cline { 2 - 3 } & Negative & -.080 \\
\hline Test Statistic & .113 \\
\hline Asymp. Sig. (2-tailed) & $.200^{\text {c,d }}$ \\
\hline \multicolumn{2}{|l|}{ a. Test distribution is Normal. } \\
\hline b. Calculated from data. \\
\hline
\end{tabular}

Sumber Tabel: Data Olah SPSS (2020) 
Berdasarkan tabel diatas menunjukkan bahwa model regresi nilai Asymp. Sig (2-tailed) sebesar 0,200. Maka dapat disimpulkan bahwa nilai signifikan 0,200 lebih besar 0,05 (0,200 > $0,05)$, sehingga data penelitian ini dapat diaktakan berdistribusi normal.

\section{Uji Multikonearitas}

Uji Multikolinieritas untuk menguji apakah variabel bebas ditemukan korelasi terhadap variabel terikat. Uji multikolinieritas di lihat dari tolerance dan VIF (variance inflationfactor). Nilai tolerance $<0,10$ dan nilai $V I F<10$, hasil uji multikolinieritas sebagai berikut:

Tabel 4. Uji Multikonearitas

\begin{tabular}{|l|r|r|r|r|}
\hline \multicolumn{5}{|c|}{ Coefficients $^{\mathrm{a}}$} \\
\hline \multirow{2}{*}{ Model } & \multicolumn{2}{|c|}{$\begin{array}{c}\text { Unstandardized } \\
\text { Coefficients }\end{array}$} & \multicolumn{2}{c|}{ Collinearity Statistics } \\
\cline { 2 - 6 } & \multicolumn{1}{|c|}{ B } & Std. Error & Tolerance & \multicolumn{1}{c|}{ VIF } \\
\hline \multirow{2}{*}{11.538} & 1.311 & & \\
\hline KOI & -1.459 & 3.106 & .533 & 1.875 \\
\hline KOA & -.700 & .322 & .656 & 1.524 \\
\hline KEI & 1.976 & .805 & .542 & 1.844 \\
\hline KUA & .318 & .404 & .587 & 1.702 \\
\hline \multicolumn{7}{|l|}{ a. Dependent Variable: TXE_Transform } \\
\hline
\end{tabular}

Sumber Tabel: Data Olah SPSS (2020)

Berdasarkan tabel diatas menunjukkan bahwa pengujian multikolinieritas tidak ada variabel independen yang mempunyai nilai tolerance $<0,10$ dan nilai $V I F>10$.

\section{Uji Autokorelasi}

Uji autokorelasi berguna untuk menguji apakah regresi linier ini ada korelasi anatara kesalahan pengguna periode saat ini dengan kesalahan autokorelasi periode sebelumnya. Tindakan autokorelasi tersebut diuji menggunakan uji Run Test, maka hasil pengujian sebagai berikut:

Tabel 5. Uji Autokorelasi

\begin{tabular}{|l|c|r|r|r|r|}
\hline \multicolumn{5}{|c|}{ Model Summary $^{\mathbf{b}}$} \\
\hline Model & $\mathrm{R}$ & R Square & $\begin{array}{c}\text { Adjusted R } \\
\text { Square }\end{array}$ & $\begin{array}{r}\text { Std. Error of } \\
\text { the Estimate }\end{array}$ & $\begin{array}{c}\text { Durbin- } \\
\text { Watson }\end{array}$ \\
\hline 1 & $.644^{\mathrm{a}}$ & .296 & .262 & .48660 & 1.882 \\
\hline
\end{tabular}

a. Predictors: (Constant), KUA, KEI, KOA, KOI

b. Dependent Variable: TAX

Sumber Tabel: Data Olah SPSS (2020)

Dari tabel diatas menunjukkan bahwa nilai D-W sebesar 1,582, maka terdapat 4 variabel $(\mathrm{k}=4)$ dan sampel sebanyak 40 perusahaan $(n=40)$. Berdasarkan tabel $\mathrm{D}-\mathrm{W}$ dengan signifikan sebesar $5 \%$ dapat ditentukan nilai (du) sebesar 1,7209, maka nilai du $<$ D-W < (4-du) adalah 1,7209 < 1,882 $<2,2791$ yang berarti tidak terjadi autokorelasi.

\section{Uji Heterokedastisitas}

Pengujian ini bertujuan untuk menguji dalam model regresi ada atau tidak terjadinya ketidaksamaan variable dari residual satu ke pengamatan yang lain. Jika residual dari pengamatan 
satu dengan yang lain tetapmaka di sebut sebagai homokedastisitas dan jika berbeda maka disebut heterokedastisitas. Model regresi yang baiktidak terjadinya heterokesdastisitas. Mengenai hasil uji heteroskedasitisitas dapat dilihat pada tabel berikut:

Tabel 6. Uji Heteroskedastisitas

\begin{tabular}{|c|c|c|c|c|c|}
\hline \multicolumn{6}{|c|}{ Coefficients $^{\mathrm{a}}$} \\
\hline \multirow[b]{2}{*}{ Model } & \multicolumn{2}{|c|}{$\begin{array}{l}\text { Unstandardized } \\
\text { Coefficients }\end{array}$} & \multirow{2}{*}{$\begin{array}{c}\text { Standardized } \\
\text { Coefficients }\end{array}$} & \multirow[b]{2}{*}{$\mathrm{t}$} & \multirow[b]{2}{*}{ Sig. } \\
\hline & B & Std. Error & & & \\
\hline 1 (Constant) & 1.557 & .627 & & 2.483 & .022 \\
\hline KOI & -2.419 & 1.486 & -.438 & -1.628 & .118 \\
\hline KOA & -.230 & .154 & -.363 & -1.496 & .149 \\
\hline KEI & .669 & .385 & .464 & 1.738 & .097 \\
\hline KUA & -.128 & .193 & -.169 & -.661 & .516 \\
\hline ende & riabl & ES2 & & & \\
\hline
\end{tabular}

Sumber Tabel: Data Olah SPSS (2020)

\section{Analisis Regresi Linear Berganda}

Analisis regresi linier berfungsi untuk menegtahui pengaruh kepemilikan institusional, komisaris independen, komite audit dan kualitas audit terhadap tax avoidance.

Tabel 7. Hasil Uji Linear Berganda

\begin{tabular}{|c|c|c|c|}
\hline \multicolumn{4}{|c|}{ Coefficients $^{a}$} \\
\hline \multirow[b]{2}{*}{ Model } & \multicolumn{2}{|c|}{$\begin{array}{c}\text { Unstandardized } \\
\text { Coefficients }\end{array}$} & \multirow{2}{*}{$\begin{array}{c}\text { Standardized } \\
\text { Coefficients } \\
\text { Beta }\end{array}$} \\
\hline & B & Std. Error & \\
\hline \begin{tabular}{l|l}
1 & (Constant) \\
\end{tabular} & 11.538 & 1.311 & \\
\hline KOI & -1.459 & 3.106 & -.118 \\
\hline KOA & -.700 & .322 & -.492 \\
\hline KEI & 1.976 & .805 & .610 \\
\hline KUA & .318 & .404 & .188 \\
\hline
\end{tabular}

Sumber Tabel: Data Olah SPSS (2020)

Dari hasil tabel diatas dapat diperoleh persamaan regresi sebagai berikut:

$\mathrm{Y}=11,538+(-1,459$. KOI $)+(-0,700$. KOA $)+(1,976$. KEI $)+(0,318$. KUA $)+$ e Dan interperetasinya adalah sebagai berikut:

1. Konstanta (a). Jika semua variabel bebas memiliki nilai nol maka nilai variabel terikat (Beta) sebesar 11,538.

2. Komisaris Independen (KOI) variabel bebas bernilai sebesar $(-1,459)$ terhadap variabel terikat, yang berati bahwa mempunyai resiko sistematis dengan setiap penurunan satuan Komisaris Indepeden akan menaikan variabel dependen sebesar $(-1,459)$ dengan asumsi variabel bebas yang lain dari model regresi adalah tetap.

3. Komite Audit (KOA) variabel bebas bernilai sebesar $(-0,700)$ terhadap variabel terikat, yang berati bahwa mempunyai resiko sistematis dengan setiap kenaikan satuan Komite Audit akan menurunkan variabel dependen sebesar $(-0,700)$ dengan asumsi variabel bebas yang lain dari model regresi adalah tetap.

4. Kepemilikan Institusi (KEI) variabel bebas bernilai sebesar 1,976 terhadap variabel terikat, yang berati bahwa mempunyai resiko sistematis dengan setiap kenaikan satuan Kepemilikan Institusi akan menurunkan variabel dependen sebesar 1,976 dengan asumsi variabel bebas yang lain dari model regresi adalah tetap.

5. Kualitas Audit (KUA) variabel bebas bernilai sebesar 0,318 terhadap variabel terikat, yang 
berati bahwa mempunyai resiko sistematis dengan setiap kenaikan satuan kualitas audit akan menurunkan variabel dependen sebesar 0,318 dengan asumsi variabel bebas yang lain dari model regresi adalah tetap.

\section{Uji Secara Persial (Uji t)}

Uji t dikenal dengan uji parsial, yaitu untuk menguji bagaimana pengaruh masing-masing variabel bebasnya terhadap variabel terikatnya. Kriteria pengujiannya adalah $t$ hitung $>t$ tabel dengan nilai signifikansi 0,05 . Hasil pengujian dengan uji ini adalah sebagai berikut:

Tabel 8. Uji t

\begin{tabular}{|c|c|c|c|c|c|}
\hline \multicolumn{6}{|c|}{ Coefficients $^{\mathrm{a}}$} \\
\hline \multirow[b]{2}{*}{ Model } & \multicolumn{2}{|c|}{$\begin{array}{l}\text { Unstandardized } \\
\text { Coefficients }\end{array}$} & \multirow{2}{*}{$\begin{array}{c}\text { Standardized } \\
\text { Coefficients } \\
\text { Beta }\end{array}$} & \multirow[b]{2}{*}{$\mathrm{t}$} & \multirow[b]{2}{*}{ Sig. } \\
\hline & B & Std. Error & & & \\
\hline 1 (Constant) & 11.538 & 1.311 & & 8.804 & .000 \\
\hline KOI & -1.459 & 3.106 & -.118 & -.470 & .643 \\
\hline KOA & -.700 & .322 & -.492 & -2.176 & .041 \\
\hline KEI & 1.976 & .805 & .610 & 2.454 & .023 \\
\hline KUA & .318 & .404 & .188 & .787 & .440 \\
\hline
\end{tabular}

Sumber Tabel: Data Olah SPSS (2020)

Berdasarkan tabel dapat dijelaskan sebagai berikut:

1. Komisaris indepeden (KOI) mempunyai nilai t hitung $<\mathrm{t}$ table yaitu dengan nilai $0,470<$ 2,02108 yang mempunyai nilai signifikan sebesar $0,643>0,05$. Berarti komisartis independen tidak mempunyai pengaruh signifikan terhadap tax avoidance.

2. Komite audit (KOA) mempunyai nilai thitung $>t$ table yaitu dengan nilai $-2,176>2,02108$ yang mempunyai nilai signifikan sebesar $0,041<0,05$. Berarti Komite audit mempunyai pengaruh negatif signifikan terhadap tax avoidance.

3. Kepemilikan institusional (KEI) mempunyai nilai t hitung $>t$ table yaitu dengan nilai 2,454 $>2,02108$ yang mempunyai nilai signifikan sebesar $0,023<0,05$. Berarti kepemilikan institusional berpengaruh positif signifikan terhadap tax avoidance.

4. Kualitas audit (KUA) mempunyai nilai t hitung $<\mathrm{t}$ table yaitu dengan nilai $0,787<2,02108$ yang mempunyai nilai signifikan sebesar $0,440<0,05$. Berarti tidak pengaruh terhadap tax avoidance.

\section{Koefisien Determinasi}

Koefisien Determinan (R Square) berguna untuk menguji seberapa jauh kemampuan model ini untuk menjelaskan variabel bebas atau variabel terikat.

Tabel 9. Koefisien Determinasi

\begin{tabular}{|l|c|c|c|c|}
\hline \multicolumn{5}{|c|}{ Model Summary } \\
\hline Model & $\mathrm{R}$ & R Square & $\begin{array}{c}\text { Adjusted R } \\
\text { Square }\end{array}$ & $\begin{array}{c}\text { Std. Error of the } \\
\text { Estimate }\end{array}$ \\
\hline 1 & $.844^{\mathrm{a}}$ & .496 & .362 & 1.68660 \\
\hline a. Predictors: (Constant), KUA, KEI, KOA, KOI \\
Sumber Tabel: Data Olah SPSS (2020) \\
Sula
\end{tabular}

Dilihat dari hasil tabel di atas bisa dilihat dapat disimpulkan bahwa Adjusted R Squer nilai Komisaris independen, komite audit, kepemilikan institusional dan kualitas audit berpengaruh sebesar 36\% terhadap tax avoidance sedangakan sisanya saebesar 64\% dipengaruhi oleh variabel lain 


\section{PEMBAHASAN \\ Pengaruh Komisaris Independen terhadap Tax Avoidance}

Berdasarkan hasil uji t dapat dilihat bahwa komisaris independen tidak berpengaruh terhadap tax avoidance dengan nilai t hitung lebih kecil dari t tabel atau $0,470<2,02108$ dan nilai signifikansi sebesar 0,643>0,05. Hal ini menunjukkan bahwa komisaris independen tidak berpengaruh terhadap tax avoidance. Dengan demikian H1 ditolak.

Hasi uji t menunjukkan bahwa komisaris independen tidak pengaruh terhadap tax avoidance karena komisarin independen tidak menunjukkan independennya sehingga pengawasan terhadap manajemen tidak berjalan secara baik. Selain itu, dewan komisaris independen tidak tanggap terhadap praktik-praktik tax avoidance dalam perusahaan sehingga melalaikan kewajiabannya sebagai pengawas.

Penelitian ini didukung oleh penelitian Rahmi Fadhilah (2014) bahwa dewan komisaris independen tidak mempengaruhi tax avoidance karena melalaikan kewajibannya sebagai komisaris independen sehingga manejer melakukan tax avoidance. Ini juga sejalan dengan penelitian Sefiana (2010) bahwa besar-kecil proporsi dewan komisaris independen tidak mempengaruhi tax avoidance karena sulit koordinasi antar komisaris independen sehingga manejer berkesempatan melakukan tax avoidance.

\section{Pengaruh Komite Audit terhadap Tax Avoidance}

Berdasarkan hasil uji t dapat dilihat bahwa komite audit berpengaruh negatif terhadap tax avoidance dengan nilai t hitung lebih besar dari t tabel atau 1,176>2,02108 dan nilai signifikansi sebesar $0,041<0,05$. Hal ini menunjukkan bahwa komite audit berpengaruh negatif terhadap tax avoidance. Dengan demikian $\mathrm{H} 2$ diterima.

Komite audit berpengaruh positif terhadap tax avoidance karena, jika komite audit semakin sedikit yang dimiliki oleh perusahaan maka pengendalian kebijakan keuangan sangat minim sehingga tindakan manajemen akan berluang besar melakukan tax avoidance. Sebaliknya jika perusahaan memiliki banyak komite audit.

Penelitian ini didukung oleh penelitian Rahmi Fadhilah (2014) bahwa komite audit berpengaruh positif terhadap tax avoidance karena sedikit atau banyak komite audit berpengaruh terhadap kebijakan keuangan. Penelitian ini sejalan dengan penelitian Sriwedari (2009) kredibilitas pelaporan keuangan tidak dapat berjalan dengan baik apabila tidak ada dukungan dari seluruh elemen dari dalam perusahaan termasuk komite audit yang bertugas dalam pengendalian kebijakan keuangan terutama dalam hal pajak di perusahaan.

\section{Pengaruh Kepemilikan Institusional terhadap Tax Avoidance}

Berdasarkan hasil uji t dapat dilihat bahwa kepemilikan institusional berpengaruh positif terhadap tax avoidance dengan nilai t hitung lebih besar dari t tabel atau 2,454 > 2,02108 dan nilai signifikansi sebesar $0,023<0,05$. Hal ini menunjukkan bahwa kepemilikan institusional berpengaruh positif terhadap tax avoidance. Dengan demikian H3 diterima.

Kepemilikan institusional berpengaruh positif terhadap tax avoidance karena semakin tinggi kepemilikan institusional, maka semakin tinggi pula jumlah beban pajak yang harus dibayarkan oleh perusahaan. Sehingga kepemilikan institusional menginginkan beban pajak yang ringan.

\section{Pengaruh Kualitas Audit terhadap Tax Avoidance}

Berdasarkan hasil uji $\mathrm{t}$ dapat dilihat bahwa kualitas audit tidak berpengaruh terhadap tax avoidance dengan nilai t hitung lebih besar dari t tabel atau $0,787<2,02108$ dan nilai signifikansi sebesar 0,440 >0,05. Hal ini menunjukkan bahwa kualitas audit tidak berpengaruh terhadap tax avoidance. Dengan demikian H4 ditolak.

Kualitas audit tidak berpengaruh terhadap tax avoidance karena perusahaan yang diaudit oleh KAP The big four memang lebih cendrung dipercayai oleh fiskus sebagai KAP yang mempunyai integritas kerja yang tinggi dengan selalu menerapkan peraturanperaturan yang ada serta 
berkualitas, namun demikian jika perusahaan bisa memberikan keuntungan dan kesejahteraan yang banyak dan lebih baik terhadap KAP tersebut bisa saja KAP yang mempunyai reputasi yang baik melakukan tindakan kecurangan untuk memaksimalkan kesejahteraan mereka.

\section{KESIMPULAN}

Penelitian menguji apakah Good corporate governance (komite audit, dewan kmisaris, kepemilikan institusional dan kualitas audit) berpengaruh terhadap tax avoidance pada perusahaan pertambangan yang terdaftar di BEI 2015-2018. Dari hasil penelitian ini dapat disimpulkan bahwa:

1. kepemilikan institusional tidak berpengaruh terhadap tax avoidance pada perusahaan pertambangan yang terdaftar di BEI 2015-2018?

2. Dewan komisaris independen berpengaruh negatif terhadap tax avoidance pada perusahaan pertambangan yang terdaftar di BEI 2015-2018?

3. Komite audit berpengaruh positif terhadap tax avoidance pada perusahaan pertambangan yang terdaftar di BEI 2015-2018?

4. Kualitas audit tidak berpengaruh terhadap tax avoidance pada perusahaan pertambangan yang terdaftar di BEI 2015-2018?

\section{REFERENSI}

Annisa N. A \& Kurniasih L. (2012). Pengaruh Corporate Governance terhadap Tax Avoidance. Jurnal Akuntansi \& Auditing. Vol. 8, No. 2. Mei 2012.

Annisa, Nuralifmida Ayu. Pengaruh Corporate Governance terhadap Tax Avoidance (Studi Pada Perusahaan Terdaftar di BEI Tahun 2008). Skripsi. Fakultas Ekonomi dan Bisnis Universitas Sebelas Maret, 2011

DDT (2019) Sektor Pertambgan Rawan Manipulasi Transfer Pricing.https://news.ddtc.co.id/sektor-pertambangan-rawan-manipulasi-transfer-pricing17422 ?page $\_$=918 di akses Juli 2020.

Dewi, N. K. dan Jati I. K. (2014). Pengaruh Karakter Ekdekutif, Karakteristik Perusahaan, dan Dimensi Tata Kelola Perusahaan yang Baik Pada Tax Avoidance di Bursa Efek Indonesia. E-Jurnal Akuntansi Universitas Udayana Vol. 6, No. 2, 2014: 249-260.

Dyreng Scott D, Hanlon Michelle, Maydew Edward L, (2008). Long-Run Corporate Tax Avoidance. The Accounting Review. Vol. 83. No. 1. Pp. 6182.

Fadhilah, Rahmi.2014 Pengaruh Good Corporate Governance Terhadap Tax Avoidance (Studi Empiris Pada Perusahaan Manufaktur Yang Terdaftar Di Bei 2009-2011). E-Jurnal Akuntansi Universitas Negeri Padang (2014), Vol.13 No. 2.

Pohan, H. T. (2008). Pengaruh Good Corporate Governance, Rasio Tobin's q, Perata Laba terhadap Penghindaran Pajak pada Perusahaan Publik. http://hotmanpohan.blogspot.com

Randal, Beasly, Aren \& Jusuf. (2013). Jasa Audit dan Assurance. Pendekatan Terpadu (Adaptsi Indonesia), Buku I. Jakarta. Salemba Empat.

Sandy dan Lukviarman. (2015).Pengaruh Corporate Governance Terhadap Tax Avoidance: Studi Empiris Pada Perusahaan Manufaktur. JAAI Volume 19 No.2, Desember 2015: 85-98.

Sefiana, Eka. 2010. Pengaruh Penerapan Corporate Governance terhadap ManajemenLaba pada Perusahaan Perbankan. http://gunadarma.ac.id

Sihaloho dan Pratomo. (2014). Pengaruh Corporate Governance Dan Karakteristik 
Owner: Riset \& Jurnal Akuntansi

e-ISSN : 2548-9224 |p-ISSN : 2548-7507

Volume 5 Nomor 1, Februari 2021

Sillagan, H, dan M. Machfoedz. (2006). Mekanisme Corporate Governance, Kualitas Laba dan Nilai Perusahaan. Simposium Nasional Akutansi IX. 24-25 Agustus 2006. Padang

Sriwedari (2009). Pengaruh Good Corporate Governance terhadap Laba dan Kinerja Perusahaan. Semarang.

Sriwedari, Tuti. (2009). Mekanisme Good Corporate Governance, Manajemen Laba dan Kinerja Keuangan Perusahaan Manufaktur di Bursa Efek Indonesia. http://eprints.unsut.ac.id

Sugiyono. (2014). Metode Penelitian Kuantitatif Kualitatif dan R\&D. Bandung: Alfabeta.

Sujoko. (2006). Pengaruh Struktur Kepemilikan, Strategi Diversifikasi, Leverage, Faktor Ekstern terhadap Nilai Perusahaan. Ekuitas. Vol.11 No.2 Maret 2007

Sumatri, Aggraeni \& Kusnawan. (2018). Corporate Governance terhadap Tax Avoidance pada Perusahaan Manufaktur yang Terdaftar di Bursa Efek Indonesia. eCo-Buss. Vol. 1, No. 2, Desember 2018.

Winata F. (2014). Pengaruh Corporate Governance Terhadap Taxavoidance Pada Perusahaan Yang Terdaftar Di Bursa Efek Indonesia Tahun 2013. TAX \& ACCOUNTING REVIEW, VOL. 4, NO.1, 2014 